\title{
Evaluating Azoxystrobin Seed Coating Against Maize Late Wilt Disease Using a Sensitive qPCR-Based Method
}

Ofir Degani, ${ }^{\dagger}$ Daniel Movshowitz, and Shlomit Dor, Tel-Hai College, Upper Galilee, Tel-Hai, 12210, Israel, and Migal-Galilee Research Institute, Kiryat Shmona, 11016, Israel; Ari Meerson, Migal-Galilee Research Institute, Kiryat Shmona, 11016, Israel; Yuval Goldblat, Tel-Hai College, Upper Galilee, Tel-Hai, 12210, Israel, and Migal-Galilee Research Institute, Kiryat Shmona, 11016, Israel; and Onn Rabinovitz, Ministry of Agriculture, Consultation Service (Shaham), Beit-Dagan, Israel

\begin{abstract}
Harpophora maydis, a phytopathogenic fungus, causes late wilt, a severe vascular maize disease characterized by relatively rapid wilting of maize plants near fertilization. The disease is currently controlled using resistant varieties. Here, we evaluated seed coating efficiency with azoxystrobin against $H$. maydis in a series of in vitro and in vivo trials. A real-time polymerase chain reaction (qPCR)-based method was developed and proved to be a sensitive, accurate tool for monitoring H. maydis DNA inside infected seeds, sprouts, and tissues of mature plants. In the early growth stages, the chemical coating drastically reduced the pathogen DNA prevalence in host tissues and minimized the suppressing effect

on the plants' biomass and development. In an infested field, the qPCR assay identified the pathogen 20 days after seeding, up to a month before conventional PCR detection. In the resistant fodder maize cultivar 32D99, which showed only minor disease symptoms, the seed coating blocked fungal progression and increased cob and plant weight by 39 and $60 \%$, respectively. Nevertheless, this treatment was unable to protect a sensitive maize hybrid, cultivar Prelude, at the disease wilting breakout (60 days after sowing). These results encourage further examination of azoxystrobin and other fungicides in the field using the qPCR detection method to evaluate their efficiency.
\end{abstract}

Harpophora maydis, the causal agent of late wilt or black bundle disease of Zea mays (corn, maize), is a soilborne and seedborne phytopathogenic fungus (Michail et al. 1999; Samra et al. 1966). H. maydis is also recognized by the synonyms Cephalosporium maydis (Samra, Sabet, and Hingorani) and Acremonium maydis (Gams 1971; Samra et al. 1966), and no perfect stage has been identified (Saleh and Leslie 2004). Late wilt was first identified in Egypt (Sabet et al. 1961) and later reported in India (Payak et al. 1970), Hungary (Pecsi and Nemeth 1998), Tanzania, Pakistan, Kenya (Freeman and Ward 2004), Romania (Bergstrom et al. 2008), Spain, Portugal (Molinero-Ruiz et al. 2010), Israel (Drori et al. 2013), and Nepal (Subedi 2015). H. maydis caused severe economic losses in Egypt (El-Hosary and El-Fiki 2015), India (Singh and Siradhana 1987), and Israel (Degani and Cernica 2014), with 100\% infection and total yield loss reported in some fields.

The disease's main symptom is a relatively rapid wilting of maize plants, typically before tasseling (at the age of 70 to 80 days) and until shortly before maturity. First symptoms appear nearly 50 to 60 days after sowing (DAS) (Sabet et al. 1970b) and include dehydration of the lower leaves. With disease progression, the lower stem surface color alters, the stem gradually dries out (especially at the internodes), and the stem has a hollow shrunken appearance, with dark yellow to brownish decomposed pith and brownish vascular bundles (Degani and Cernica 2014). Infection also resulted in a reduction of the number of vascular bundles in the cross-section of the internode (Abd El-Rahim et al. 1998). Interestingly, filtrates of $H$. maydis had deleterious effects on grain germination, seedling growth, and water conductivity in shoot parts (El-Gremi et al. 2007).

${ }^{\dagger}$ Corresponding author: Ofir Degani; E-mail: d-ofir@bezeqint.net, ofird@telhai.ac.il

Funding: This work was supported by a research grant from the Israel Ministry of Agriculture and Rural Development (grant no. 21-35-0003), the chief scientist, and a research grant from the Israel Northern R\&D, Migal - Galilee Research Institute, Kiryat Shmona, Israel.

Accepted for publication 19 July 2018.

() 2019 The American Phytopathological Society
Infection by secondary invaders is often associated with late wilt, causing the stem symptoms to become more severe (El-Shafey and Claflin 1999; Samra et al. 1962). Indeed, the postflowering stalk rot complex, which includes a number of fungi (such as Fusarium verticillioides causing Fusarium stalk rot, Macrophomina phaseolina causing charcoal rot, and H. maydis), is one of the most severe, destructive, and widespread groups of diseases in maize (Khokhar et al. 2014). In heavily infested fields and sensitive maize hybrids, fewer ears are formed, and if kernels are produced, they are poorly developed and may be infested with the pathogen (Drori et al. 2013). Seed quantity is correlated negatively with disease severity (Shehata 1976). The pathogen is considered a poor competitor when compared with other microorganisms in the soil (Sabet et al. 1970b), and its spore germination and hyphal development react differently to various ambient conditions (Degani and Goldblat 2014).

More maize is produced on a yearly basis than any other grain, reflecting its importance in the global market for food and feed production, as well as industrial processes, primarily ethanol production for use in biofuels (Anderson et al. 2015). Given the ability of $H$. maydis to survive and spread through the movement of infested soil, crop residue (Sabet et al. 1970a), seed-borne inoculum (Michail et al. 1999), or secondary hosts (Sabet et al. 1966; Sahab et al. 1985), the importance of controlling this pathogen effectively, for both commercial grain production and maize seed production, has increased over the years. Although some agricultural (balanced soil fertility and flood fallowing) (Samra et al. 1966; Singh and Siradhana 1990), biological (El-Assiuty et al. 1991; El-Mehalowy et al. 2004; Muhammad and Amusa 2003; Singh and Siradhana 1988), physical (solar heating) (Fayzalla et al. 1994), and chemical controls (Abdel-Rahim et al. 1982; Degani et al. 2014) were able to reduce the pathogen's impact on commercial production, none of these methods is currently used in Israel. At present, late wilt disease is controlled by more economically effective management through continuous efforts to develop genetically resistant maize cultivars (El-Hosary and ElFiki 2015; El-Shafey et al. 1988), but little information is available in the literature on the pathogen's development in those apparently asymptomatic maize varieties. Moreover, the presence of highly virulent isolates of $H$. maydis (Ortiz-Bustos et al. 2016; Zeller et al. 2002) may threaten these resistant maize cultivars. Indeed, isolates of $H$. maydis differ, not only in pathogenicity but also in morphology and route of infection (Warren 1983). For example, Egyptian isolates of $H$. maydis were classified into four clonal lineages, which revealed 
diversity in virulence and colonization ability on maize (El-Assiuty et al. 1991; Saleh et al. 2003; Zeller et al. 2002). In southern Portugal and Spain, 14 isolates of $H$. maydis were analyzed by inoculating a susceptible maize cultivar (Ortiz-Bustos et al. 2016). One of the isolates caused significant reductions in the weight of both aboveground parts and roots. This isolate was also highly aggressive and was able to cause intense symptoms.

It was also demonstrated that the pathogen could spread in relatively resistant maize plants that were nonsymptomatic (Drori et al. 2013) and that seeds of these apparently healthy, reduced-sensitivity plants may therefore also spread the disease. Commercially available hybrids often lack a high level of resistance to this pathogen. Thus, chemical control is a common strategy in high-risk areas. H. maydis can be isolated from symptomatic plants and identified using morphological characteristics, but this procedure requires considerable taxonomic expertise and time. Also, as noted by Saleh et al. (2003), recovery of $H$. maydis is difficult, even from heavily infested material, owing to its slow growth and the relative abundance of other more rapidly growing fungi, particularly Fusarium spp.

The presence of species-specific polymerase chain reaction (PCR) primers enables distinguishing $H$. maydis from other species in the Gaeumannomyces-Harpophora complex (Saleh and Leslie 2004). These primers were used as a diagnostic assay to track disease progression in an infested field in northern Israel (Drori et al. 2013). This molecular method, together with morphological approaches, was used for evaluating the effect of selected fungicides on the pathogen in a series of trials, starting from an in vitro culture plate assay, followed by a detached root pathogenicity assay, and eventually a seedling inoculation assay (Degani and Cernica 2014).

These methods have several advantages, but they should be considered in a critical manner. The in vitro plate assays and even the seedling pot assays, despite their inconsistent ability to predict results in the field (Sabet et al. 1972), are important preliminary steps in ruling out ineffective treatments and in choosing the ones having the highest probability to succeed. A scientific program directed toward developing disease control cannot be established exclusively on field experiments during the growing season owing to the great efforts involved in such experiments, the long period until results are received, and the changes in environmental conditions that cause inconsistency in the results.

Although PCR was proven to be an important method for tracking pathogenesis in host plants (Drori et al. 2013), its sensitivity is limited. For example, the PCR method is only capable of revealing variations in the amount of fungal DNA in plant tissues above threshold levels according to band intensity and can detect $H$. maydis DNA in field experiments only from days 40 to 50 onward. In sprouts in a greenhouse, this method identified fungal DNA in the host root and stem tissues 22 DAS (Degani and Cernica 2014), but it was hard to repeat this work. In most experiments, the PCR method fails to detect the pathogen DNA in host tissues, even 40 days after planting, owing to its relatively low concentrations (O. Degani et al., unpublished data). Thus, a more sensitive and accurate molecular method is necessary.

The current work focuses on two research lines: (i) the assessment of the efficacy of seed dressing with azoxystrobin (AS) against maize late wilt, which is done in vitro as well as in vivo (incubator, growth chamber, greenhouse, and field), and (ii) the application of the realtime PCR (qPCR) protocol for the detection of fungal DNA in each of the situations mentioned. Seed germination, seedling emergence, root and shoot biomass, phenological development, wilting evaluation, yield estimation, and qPCR molecular tracking were applied to evaluate the efficiency of seed coating with AS (commercial name Amistar S.C.; manufactured by Syngenta, Basel, Switzerland; supplied by Adama Makhteshim, Ashdod, Israel) against late wilt. The seed-coating method has not yet been tested against $H$. maydis in Israel but has been proven to be successful and inexpensive in treating other soil diseases. Indeed, seed coating is a common method for protecting maize seedlings emerging from soilborne fungi and has the potential of playing an important role in defending against $H$. maydis, as demonstrated earlier (Begum et al. 1989). Because the infection initially occurs during the seedling stage, late wilt disease can be managed effectively with seed treatment fungicides; however, data available on the efficacy of specific antifungal compounds are limited. The development of a modified novel and useful qPCR assay from the previous conventional PCR assay for detecting and monitoring $H$. maydis DNA inside the host tissues is another aim of the current work. This new method, just like conventional PCR, specifically detects $H$. maydis based on the amplified fragment length polymorphism (AFLP) profile (Saleh and Leslie 2004). Similar work based on a nucleotide sequence of the fungus's ribosomal internal transcribed spacer (ITS) region has been recently reported (Costanzo et al. 2013).

\section{Materials and Methods}

Fungal isolates and growth conditions. One representative isolate of $\mathrm{H}$. maydis called $\mathrm{Hm}-2$ (CBS 133165) was selected for this study from our isolate library. This isolate is currently deposited in the CBS-KNAW Fungal Biodiversity Center, Utrecht, the Netherlands. Like the other isolates (also deposited in CBS-KNAW in the same collection), this $H$. maydis strain was recovered from wilting maize plants (Zea mays L. 'Jubilee', from Pop Vriend Seeds B.V., Andijk, the Netherlands, supplied by Eden Seeds, Reut, Israel) sampled from a maize field in Sde Nehemia in the Hula Valley in the Upper Galilee (northern Israel) in 2001. The Israeli H. maydis isolates (including this representative strain) were previously characterized by their pathogenicity, physiology, colony morphology, and microscopic traits (Degani and Goldblat 2014; Drori et al. 2013). The morphological and microscopic characteristics of the pathogen were similar to strains previously described in Egypt and India (Payak et al. 1970; Samra et al. 1963). Using PCR-based DNA analysis (Drori et al. 2013), a final confirmation of those strains was achieved.

All fungal colonies were grown on potato dextrose agar (PDA) (Difco, Detroit, MI) at $28 \pm 1^{\circ} \mathrm{C}$ in complete darkness for 4 to 7 days. To prepare inocula in a liquid medium, we added six 6-mm-diameter agar disks cut from the margins of an $H$. maydis colony (grown as described above) to $150-\mathrm{ml}$ of sterile potato dextrose broth in a 250-ml Erlenmeyer flask. Cultures were grown at $28 \pm 1{ }^{\circ} \mathrm{C}$ in the dark on a rotary shaker at $150 \mathrm{rpm}$ for 6 to 7 days.

The H. maydis pathogenic behavior tested in a series of experiments aimed at evaluating a seed coating prevention treatment, starting from in vitro (seed inoculation in an Erlenmeyer flask), followed by a seedling assay (sprouts up to the age of 5 weeks) in a growth chamber, potted plants over a full growth period in a greenhouse, and eventually a field assay. These evaluation steps will be described in detail below.

Effect of AS coating on in vitro seed infection. The first experiments in seed dressing aimed at adjusting the coating method and testing the new qPCR detection method's capability of tracking fungal DNA inside the seed tissues in comparison with the traditional PCR method. The susceptible cultivar of sweet maize (Jubilee) was chosen for the seed pathogenicity test. This cultivar was tested previously for susceptibility to late wilt (Drori et al. 2013). To examine the ability of the pathogen in infecting maize seeds in vitro, we inoculated seeds by soaking them in a fungal suspension and afterward detecting the presence of the fungus in the inner tissues. Ten seeds of the selected maize cultivar (not treated with regular seedtreatment fungicides or insecticides) were dipped in $1 \%$ (v/v) sodium hypochlorite for $3 \mathrm{~min}$, washed in sterile double-distilled water (DDW), treated with AS, and then placed in a 250-ml Erlenmeyer flask with $20 \mathrm{ml}$ of autoclaved DDW. The AS seed coating was done by dipping the seeds in $10 \mathrm{mg} /$ liter of active ingredient for $10 \mathrm{~min}$ (final concentration of approximately $0.02 \mathrm{mg} / \mathrm{seed}$ ) and then drying them. To each of the Erlenmeyer flasks containing seeds, we added three 6-mm-diameter agar disks cut from the margins of $H$. maydis colonies (grown previously on PDA at $28^{\circ} \mathrm{C}$ in the dark for 4 to 6 days), and the Erlenmeyer flasks were incubated at $28^{\circ} \mathrm{C}$ in the dark. Seed germination percentage determination and wet weight measurement of all the seeds in each treatment were conducted 1 week after inoculation. A germinating seed was defined as a seed in which the seed coat was broken by the radicle. For wet weight 
assessment, sprouts were collected at the end of the experiment and dried gently with paper towels, and the fresh biomass was measured for each bud individually using analytical scales. Inoculated, uncoated maize seeds were used as positive controls. Untreated seeds (seeds soaked only in water), coated or uncoated, were used to evaluate the phytotoxicity of the fungicide seed treatment and as negative controls.

On day 7 after inoculation, a sample of three seeds from each repeat in each treatment was washed thoroughly with a $70 \%$ ethanol solution and then with autoclaved DDW to remove any residuals of the fungus that may be attached to the seeds' surface. The seeds were ground to a powder using liquid nitrogen, and DNA was obtained with the Extract-N-amp plant PCR kit (Sigma, Rehovot, Israel) according to the manufacturer's instructions. The purified DNA was used as a template for the PCR or qPCR reaction. The PCRamplified DNA samples were identified by electrophoretic gel analysis. The experiment was conducted twice, and similar results were obtained.

Effect of AS seed coating on seedlings emerging in a growth chamber. Seed coating of the maize cultivar Jubilee was performed with AS fungicide, as described above for the in vitro seed infection. In the preliminary experiments, several inoculation methods were compared. Data are shown only for the seed hyphae dipping and for the direct application of hyphae with the seeding, which were the most effective methods. For seed hyphae inoculation (dipping) inspection, the fungus was grown in liquid medium, as described above. The mycelium was harvested and used for seed inoculation by preincubating 10 seeds (before seeding) in a 200-mg mycelium suspension overnight. Alternatively, a 200-mg mycelium suspension was added directly to each seed with the sowing. The control plants (noninoculated plants) were grown under the same conditions.

The experiment was conducted in triplicate (data are shown only for the last experiment, but similar results were obtained for all three repetitions). Each treatment included 5 to 10 independent replications (pots). Five maize seeds were sown in a 2.5-liter pot about $4 \mathrm{~cm}$ beneath the surface. The soil mix (Shacham Givat Ada, Givat Ada, Israel) was commercial and nonsterilized, composed of $65 \%$ coco, $20 \%$ peat, $10 \%$ tuff (4- to 10-mm volcanic stones), and 5\% Multicote Agri controlled-release fertilizer (Haifa Group, Haifa, Israel), w/w. Watering was done by adding $100 \pm 10 \mathrm{ml}$ of DDW every $72 \mathrm{~h}$ to the pots using a computerized irrigation system. All the plants used for the pathogenicity assay were grown in a growth chamber under a constant temperature of $28 \pm 3^{\circ} \mathrm{C}$ and relative humidity of 45 to $50 \%$ with a 12 -h photoperiod illuminated by cool-white fluorescent tubes (Philips, Eindhoven, the Netherlands).

The degree of emergence of the plants (revealing the tip of the coleoptile that grew and was aboveground) in each treatment and in the controls was determined 1 week after seeding. The seedlings were examined for phenological development and for infection by H. maydis 30 days after planting. At this age, the plants' fifth leaf had emerged, remained partly rolled, and was beginning to expand (growth stage V5, Abendroth et al. 2011). At the end of the experiment, the seedlings were cleaned of visible soil by rinsing thoroughly under running tap water and dried gently with paper towels. For wet weight assessment, the root and shoot of each sprout were separated by a scalpel, and the fresh biomass of each part was measured individually using analytical scales. The aboveground height (from the first node to the shoot tip) of each plant was measured separately.

For the DNA purification, plants were rinsed twice in sterile water for $30 \mathrm{~s}$ each time. Under a sterile biosafety hood, tissue samples were excised from the root and the near-surface hypocotyl tissues. Tissues were sampled by removing a cross-section of approximately $2 \mathrm{~cm}$ in length from each plant. Samples from the five plants of each pot were combined, and the total weight was adjusted to $0.4 \mathrm{~g}$ and considered to be one repeat. Tissue samples were placed in universal extraction bags (Bioreba, Switzerland) with $4 \mathrm{ml}$ of cetyltrimethylammonium bromide buffer, and the tissue was ground with a hand tissue homogenizer (Bioreba, Switzerland) for 5 min until the tissues were completely homogenous, according to the method of Murray and Thompson (1980), with minor modifications.
Effect of AS seed coating on mature plants in a greenhouse. The reaction of maize to $H$. maydis at late growth stages was studied in an experiment conducted in a greenhouse. In a preliminary experiment, the colony agar disk inoculation method (used in the sprout infection experiment) was incapable of causing significant symptoms in mature plants (age 70 days or more, O. Degani et al., unpublished data). We therefore used the inoculum method, consisting of a naturally infested soil taken from the maize field described below (mixed with $30 \%$ Perlite no. 4), to which complementary inoculation with the $\mathrm{Hm}-2$ isolate was carried out in two steps. First, $20 \mathrm{~g}$ of sterilized infected wheat seeds was added to the top $20 \mathrm{~cm}$ of the soil of each pot with the sowing. These seeds were previously incubated for 10 days at $28^{\circ} \mathrm{C}$ in the dark with $H$. maydis colony agar disks $(10$ disks per $100 \mathrm{~g}$ of seeds) and were used here to spread the pathogen in the soil, as described previously (Zeller et al. 2002). Second, with the aboveground appearance (on day 6 of growth), two agar disks (6-mmdiameter) from 5-day-old $H$. maydis colonies (grown as described above) were added to the upper parts of the roots $(4 \mathrm{~cm}$ beneath the ground surface), according to the method of Degani and Cernica (2014).

The late wilt-sensitive, sweet maize cultivar Prelude (from SRS Snowy River Seeds, Australia, supplied by Green 2000, Israel) was selected for this experiment. The cultivar Prelude was tested previously for susceptibility to late wilt in the field (Israel Northern R\&D, unpublished data). Each treatment included 10 independent replications (pots). The experiment was conducted twice (with similar results) and was carried out in a completely randomized design. Five untreated (control) or AS-coated seeds were planted in each 10liter pot. Thinning to two plants per pot was done 25 DAS. Seed coating was performed in a standard commercial procedure by mixing the seeds with $0.0125 \mathrm{mg}$ of active ingredient AS fungicide per seed $\left(0.002 \mathrm{~cm}^{3}\right.$ of fungicide preparation/seed, within the standard concentration range used by Syngenta AG, Basel, Switzerland) until the fungicide was completely absorbed in the seeds. The treatments and the control plants (noninoculated plants) were grown for 72 days in a greenhouse at $25 \pm 2{ }^{\circ} \mathrm{C}$ and an 8 - to 10 -h photoperiod per day. They were fertilized once (25 DAS) with $25 \mathrm{~g}$ of Multicote Agri per pot and were watered for $15 \mathrm{~min}$ with 2 liters (or more if required) in each pot every $24 \mathrm{~h}$ using a computerized irrigation line system. Emergence assessment was done as in the growth chamber experiment (described above) 7 DAS. Dehydration assessment was done on day 69 after sowing by calculating the percentage of plants that showed typical late wilt dehydration symptoms: the color alteration of the upper leaves to light silver and then to light brown, and rolling inward from the edges of the entire leaf. Harvesting was carried out on day 72. At the end of the experiment, all the replications of each treatment were uprooted, and the aboveground parts of each plant were measured to determine their height and wet weight independently (as described above for the growth chamber experiment). Dry biomass of the shoot was determined after drying at $65^{\circ} \mathrm{C}$ for $62 \mathrm{~h}$. Tissue samples were taken from the first aboveground internode to identify the fungal DNA inside the host tissues using qPCR.

Effect of AS seed coating in an infested field. A field experiment for assessing AS seed coating efficiency in controlling $H$. maydis pathogenesis was conducted during the spring and summer of 2016. Four representative maize cultivars were evaluated in this experiment: two sweet corn cultivars (the susceptible cultivar Prelude and Royalty, which is a relatively late wilt resistant variety from Pop Vriend Seeds, supplied by Eden Seeds, Reut, Israel) and two fodder cultivars (p32w86, a sensitive maize hybrid, and 32D99, a relatively resistant hybrid, both from Pioneer-DuPont, IA, supplied by Gadot Agro, Kidron, Israel). The four cultivars were used for a general evaluation of the qPCR detection method's efficiency in the field. All of the cultivars had been tested previously for late wilt disease in the field (Israel Northern R\&D, unpublished data). Two of the maize cultivars were chosen for more in-depth evaluation: the sweet susceptible cultivar Prelude and the fodder resistant cultivar 32D99. The Prelude and 32D99 cultivars were chosen to evaluate the efficiency of the AS seed coating treatment and the qPCR detection method in two extreme cultivars that differed not only in susceptibility to the disease but also in phenological and development progression, plant size, 
length of growth period, and commercial use of the yields. The experiment was performed in the southern area of a maize field (Mehogi 5 maize plot) near Kibbutz Amir in the Hula Valley (Shemesh field crops partnership, Upper Galilee, northern Israel), which has been known to be infested with late wilt for many years. This area was part of a large maize field used for grain production; the rows nearby were planted with other maize hybrids and are not included in the current study. Plots were arranged in the field using a randomized complete block design. The area included 15 plots, each containing two rows (eight plots per treatment). Each row was $12 \mathrm{~m}$ long and contained 3.3 maize plants per meter (40 plants per row). Row spacing was $96.5 \mathrm{~cm}$. Seeds were pretreated (in a common commercial procedure by Gadot Agro, Kidron, Israel) with AS at $0.0025 \mathrm{mg}$ of active ingredient per seed (within the standard concentration range used by Syngenta). The field was watered with a combination of a frontal irrigation system and a 20-mm drip irrigation line (Dripnet PC1613 F, Netafim USA, Fresno, CA) for two rows (200 and $400 \mathrm{~mm}$, respectively, per growth season in total).
Seeding was performed on 25 May 2016, and germination (with the frontal irrigation system) 1 day later. Plants emerged above the ground surface approximately 6 days after planting. Plants were first pollinated when they reached 70\% silk: cultivar Prelude 50 DAS and cultivar 32D99 56 DAS. The pollination continued for 3 days. In the cultivar Prelude plots, wilt determination was carried out 19 and 25 days after fertilization (DAF) (69 and 75 DAS) by calculating the percentage of the plants that showed typical late wilt dehydration symptoms: color alteration of the upper leaves to light silver and then to light brown, and rolling inward from the edges of the entire leaf. In the cultivar 32D99 plots, wilt determination was carried out using the same method 34 and 49 DAF (84 and 99 DAS). Yield determination included all the upper part plant cobs in a 5-m-long section of each of the experimental rows. Until harvest day (27 DAF, 77 DAS), the sensitive cultivar Prelude plots were collapsed, and total yield loss was recorded. In the fodder maize cultivar 32D99, yield determination was done 52 DAF (102 DAS) by evaluating the dry matter in the plants and cobs (representative plants were dried at $65^{\circ} \mathrm{C}$ for $48 \mathrm{~h}$ ).

Table 1. Primers for Harpophora maydis detection ${ }^{\mathrm{a}}$

\begin{tabular}{|c|c|c|c|c|c|}
\hline Pairs & Primer & Sequence & Uses & Amplification & References \\
\hline Pair 1 & $\begin{array}{r}\text { A200a-for / } \\
\text { A200a-rev }\end{array}$ & $\begin{array}{c}\text { 5'-CCGACGCCTAAAATACAGGA-3' / } \\
\text { 5'-GGGCTTTTTAGGGCCTTTTT-3' }^{\prime}\end{array}$ & PCR and $\mathrm{qPCR}$ & $\begin{array}{l}\text { H. maydis AFLP-derived } \\
\text { species-specific fragment }\end{array}$ & Drori et al. (2013) \\
\hline Pair 2 & $\mathrm{Am} 42$ / Am43 & $\begin{array}{l}\text { 5'-CAACTACGAGCTTTTTAACTGC-3' / } \\
\text { 5'-CAAATTACCCAATCCCGACAC-3' }\end{array}$ & PCR control & $\begin{array}{l}\text { Eukaryotic ribosomal DNA - } 18 \mathrm{~S} \text { rRNA gene } \\
\text { product, rDNA }\end{array}$ & $\begin{array}{l}\text { Fromont-Racine } \\
\text { et al. }(2003)\end{array}$ \\
\hline Pair 3 & COX-F/COX-R & $\begin{array}{l}\text { 5'-GTATGCCACGTCGCATTCCAGA-3' } \\
\text { / 5'-CAACTACGGATATATAA } \\
\text { GRRCCRRAACTG-3' }\end{array}$ & qPCR control & Cytochrome c oxidase gene product & Weller et al. (2000) \\
\hline
\end{tabular}

${ }^{\text {a }} \mathrm{PCR}$ = polymerase chain reaction; $\mathrm{qPCR}$ = real-time PCR; and AFLP = amplified fragment length polymorphism.

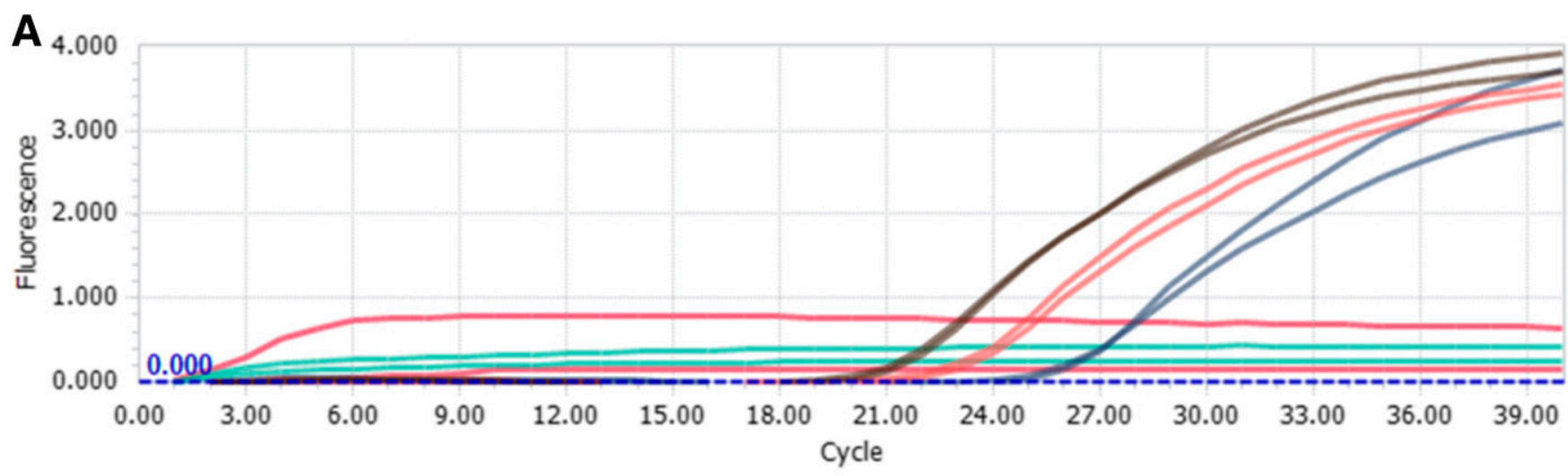

B

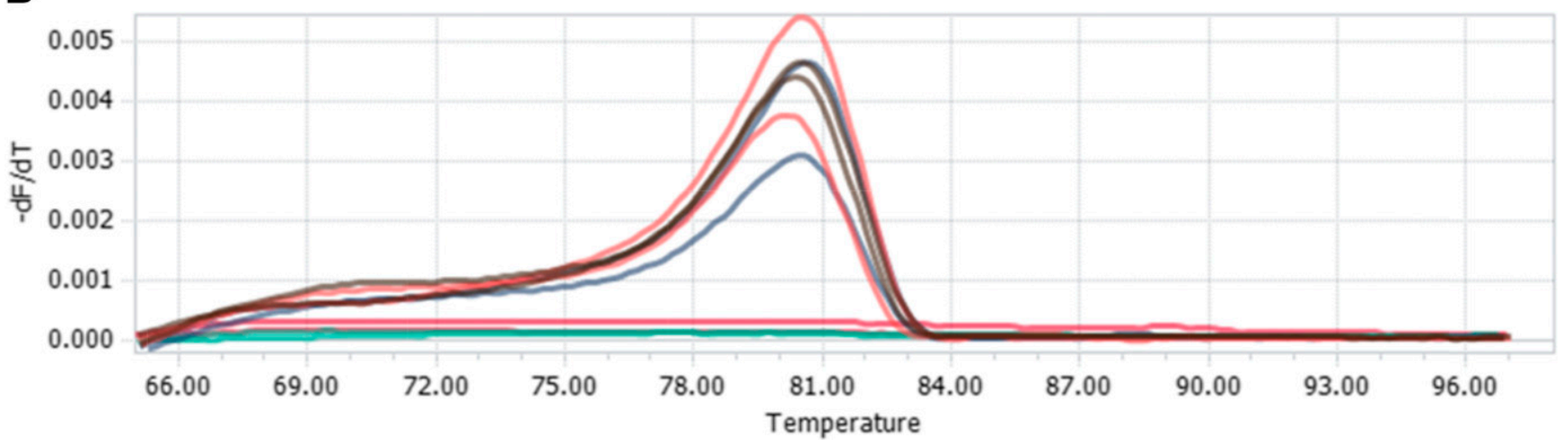

Fig. 1. Amplification and melting plots obtained by serial dilution of Harpophora maydis DNA extracted from the tissues of infected plants. The DNA was extracted from a potato dextrose agar colony. A, Jubilee maize plants (a late wilt sensitive cultivar) were grown in inoculated soil for 40 days. Samples were ground, and DNA was extracted for real-time polymerase chain reaction (qPCR) amplification of the H. maydis AFLP-derived species-specific fragment (Drori et al. 2013). The H. maydis DNA (20-, 100-, and 1,000-fold dilution) was amplified using a LightCycler 96 System. Fluorescence is expressed in relative units. Each dilution was tested in duplicate. The flat curves are negative controls: DNA from uninfected healthy plants and the double-distilled water control. The leftmost saturated curve represents a starting concentration of $15 \mathrm{pg} / \mu \mathrm{l}(20$-fold dilution). B, Melting curve analysis (also known as dissociation curve) of the DNA serial dilutions. $\mathrm{dF} / \mathrm{dT}$ reflects the change in fluorescence level with respect to per unit increase in temperature $\left({ }^{\circ} \mathrm{C}\right)$. 
Molecular diagnosis of late wilt pathogenesis in the field experiment. Three plants were collected arbitrarily from the cultivar Prelude and cultivar 32D99 plots at approximately 10-day intervals from sowing onward. Sampling was made on days 13 (roots), 22 (roots), 32 (roots), 42 (roots), 53 (roots and stems), 62 (stems), and 72 (stems) after seeding. Different plant tissues (root or stem) were sterilized separately with $70 \%$ ethanol and then washed with autoclaved DDW. DNA was extracted and analyzed as described below.

DNA extraction, PCR, and qPCR. DNA extraction and PCRbased method. DNA was obtained using the Extract-N-amp plant PCR kit (Sigma, Rehovot, Israel) according to the manufacturer's instructions or using an alternative method according to Murray and Thompson (1980). DNA was extracted directly from 7-day-old cultures grown under the above conditions, from tissue samples of axenically grown maize tissue, and from maize tissue known to be infected with $H$. maydis. All DNA samples were tested in triplicate. PCR was performed to amplify a specific $H$. maydis segment (Saleh and Leslie 2004) with a Rapidcycler (Idaho Technology, Salt Lake City, UT). Negative controls (in which water replaced the DNA template) were used to ensure the absence of primer dimers and contamination.

The A200a primer set (Table 1) amplifies a specific H. maydis 200-bp piece from an AFLP-derived species-specific fragment that was initially identified by Saleh and Leslie (2004). The Am42/Am43 primer set (Table 1) amplifies eukaryotic ribosomal DNA (18S rRNA gene product, rDNA) (Fromont-Racine et al. 2003) and was used for a
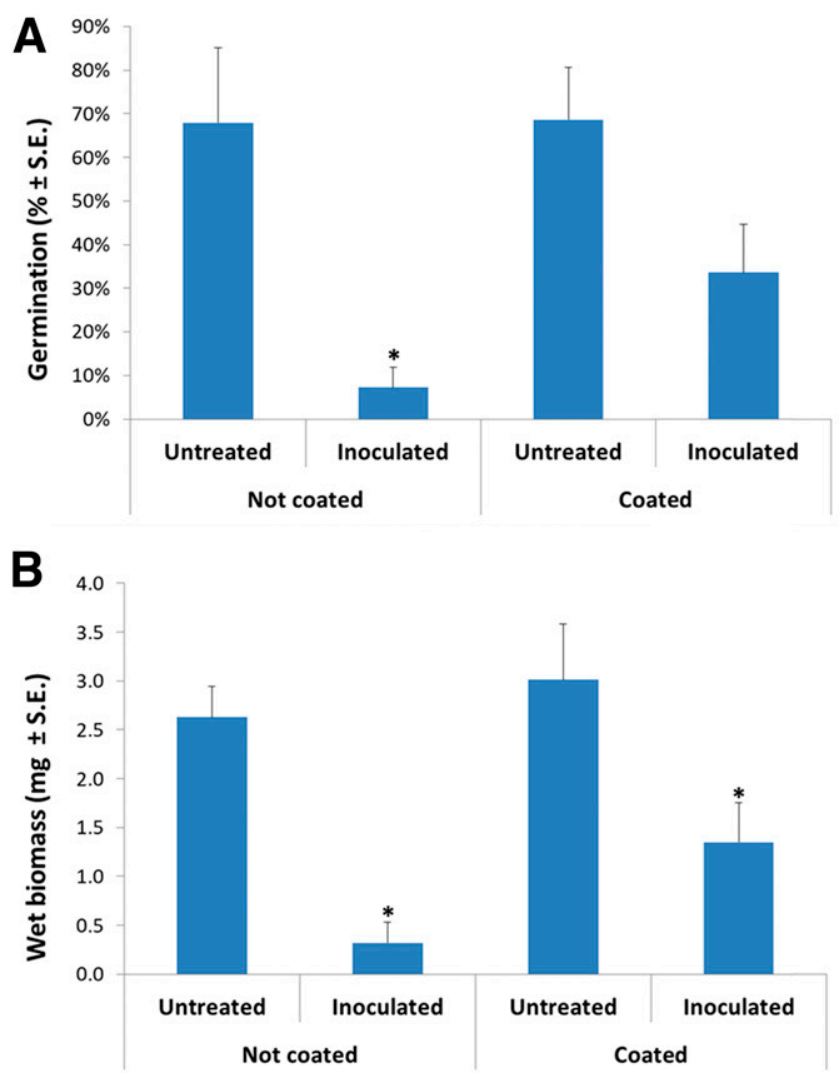

Fig. 2. Effect of azoxystrobin (AS) seed coating on in vitro seed infection. Seed germination percentage (A) and wet weight (B) of the susceptible maize genotype Jubilee upon inoculation with an isolate of Harpophora maydis grown in Erlenmeyer flasks (in vitro) for 1 week. The AS treatments included coating seeds prepared by dipping the seeds in $10 \mathrm{mg} /$ liter of AS active ingredient for $10 \mathrm{~min}$ (final concentration of approximately $0.02 \mathrm{mg} / \mathrm{seed}$ ) and then drying them. Inoculation was done by adding three 6-mm-diameter agar disks cut from the margins of $H$. maydis colonies. Untreated seeds (seeds soaked only in water), coated or uncoated, were used to evaluate the phytotoxicity of the fungicide seed treatment and as negative controls. Vertical upper bars represent the standard error of the mean of five replications (Erlenmeyer flasks, each containing 10 seeds). When existing, significance from the control (untreated) is indicated with an asterisk (*), indicating $P<0.05$. positive amplification control. Reaction mixtures were contained in a total volume of $20 \mu \mathrm{l}: 1 \mu \mathrm{l}$ of each primer ( $20 \mu \mathrm{M}$ of each primer), $4 \mu \mathrm{l}$ of Red Load Taq Master (Larova, Teltow, Germany), $3 \mu \mathrm{l}$ of DNA sample, and $11 \mu \mathrm{l}$ of sterile DDW. Cycling conditions for all primer pairs were $94^{\circ} \mathrm{C}$ for $2 \mathrm{~min}$, followed by 35 cycles of $94^{\circ} \mathrm{C}$ for $30 \mathrm{~s}, 55^{\circ} \mathrm{C}$ for $30 \mathrm{~s}$, and $72^{\circ} \mathrm{C}$ for $1 \mathrm{~min}$, and a final step of $72^{\circ} \mathrm{C}$ for $5 \mathrm{~min}$. After PCR, a 200-bp amplified DNA band was identified by electrophoresis on a $1.5 \%$ agarose gel (Lonza, Rockland, ME).

qPCR-based method. In the preliminary experiments, we ascertained that the previously published conventional PCR (Degani and Cernica 2014) was not sufficiently sensitive to detect low levels of $H$. maydis DNA in plant tissue. Therefore, we designed the A200a primers for qPCR (sequences in Table 1). All qPCR reactions were performed using the LightCycler 96 System (Roche, Basel, Switzerland) for 96-well 0.1-ml plates, or the ABI PRISM 7900 HT Sequence Detection System (Applied Biosystems, Foster City, CA) for 384-well plates. Final qPCR conditions were as follows: $20-\mu 1$ total reaction volume was used per sample well: $8 \mu$ l of sample DNA extract, $10 \mu \mathrm{l}$ of iTaq Universal SYBR Green Supermix (Bio-Rad Laboratories, Rishon Le Zion, Israel), $1 \mu \mathrm{l}$ of forward primer, and $1 \mu \mathrm{l}$ of reverse primer ( $4 \mu \mathrm{M}$ from each primer to a well). The final qPCR parameters were as follows: precycle activation stage, $5 \mathrm{~min}$ at $95^{\circ} \mathrm{C} ; 40$ cycles of denaturation $\left(1 \mathrm{~min}\right.$ at $\left.95^{\circ} \mathrm{C}\right)$, and annealing and extension $\left(30 \mathrm{~s}\right.$ at $\left.60^{\circ} \mathrm{C}\right)$, followed by melting curve analysis. A standard curve was established using 10-fold serial dilutions of DNA from direct $H$. maydis PDA plate culture extraction with a starting concentration of $300 \mathrm{ng} / \mathrm{ml}$ down to $0.3 \mathrm{ng} / \mathrm{ml}$; the resulting amplification and melting curves are shown in Figure 1. Plant tissue samples (seed, root, and stem) from each experiment were analyzed separately by qPCR. The gene coding for the last enzyme in the respiratory electron transport chain of the eukaryotic mitochondria, cytochrome $\mathrm{c}$ oxidase $(C O X)$, was used as a "housekeeping" reference gene to normalize the amount of cDNA (Weller et al. 2000). This gene product was amplified using the COX-F/COX-R primer set (Table 1). Relative gene expression was calculated according to the $\Delta \Delta \mathrm{Ct}$ model (Yuan et al. 2006). Efficiency was assumed to be the same for all samples. All amplifications were performed in triplicate.

Table 2. Efficiency of the azoxystrobin (AS) seed coating on mature plants in a greenhouse ${ }^{\mathrm{a}}$

\begin{tabular}{|c|c|c|c|c|c|}
\hline \multirow[b]{2}{*}{ Assessment } & \multirow{2}{*}{$\begin{array}{c}\text { Age (days } \\
\text { after sowing) }\end{array}$} & \multicolumn{2}{|c|}{$\mathbf{N T}^{\mathbf{b}}$} & \multicolumn{2}{|c|}{ AS } \\
\hline & & Mean & SE & Mean & SE \\
\hline Emergence & 7 & $88 \%$ & $6.8 \%$ & $60 \%{ }^{\mathrm{c}}$ & $7.5 \%$ \\
\hline $\begin{array}{l}\text { Number of green } \\
\text { leaves }\end{array}$ & 69 & 2.0 & 0.9 & 4.0 & 1.1 \\
\hline Wilting & 69 & $73 \%$ & $37 \%$ & $44 \%$ & $22 \%$ \\
\hline $\begin{array}{l}\text { Phenological } \\
\text { stage }^{\mathrm{d}}\end{array}$ & 69 & $\begin{array}{l}\text { VT, } 60 \% \\
\text { R1, } 10 \% \\
\text { R2, 30\% }\end{array}$ & $\begin{array}{l}\ldots \\
\ldots \\
\ldots\end{array}$ & $\begin{array}{l}\text { VT, } 44 \% \\
\text { R1, } 44 \% \\
\text { R2, } 12 \%\end{array}$ & $\begin{array}{l}\ldots \\
\ldots \\
\ldots\end{array}$ \\
\hline Plant height $(\mathrm{cm})$ & 72 & 117.3 & 6.8 & 118.7 & 10.1 \\
\hline $\begin{array}{l}\text { Shoot wet } \\
\text { weight }(\mathrm{g})\end{array}$ & 72 & 60.0 & 9.5 & 75.5 & 7.8 \\
\hline $\begin{array}{l}\text { Shoot dry weight } \\
\text { (g) }\end{array}$ & 72 & 14.3 & 1.2 & 17.6 & 1.5 \\
\hline $\begin{array}{l}\text { qPCR results } \\
\text { (HMRT/COX } \\
\text { ratio) }\end{array}$ & 72 & 2.14 & 1.65 & 0.19 & 0.07 \\
\hline
\end{tabular}

a The susceptible sweet maize cultivar Prelude was selected for this experiment. Seed coating was performed in a commercial common procedure by mixing the seeds with $0.0125 \mathrm{mg}$ of active ingredient AS fungicide per seed. The inoculum method consisted of a naturally infested soil taken from the maize field with complementary inoculation with the $H$. maydis isolate. Results were calculated from the mean of 10 independent replicates.

${ }^{\mathrm{b}} \mathrm{NT}=$ control, untreated plots; and $\mathrm{SE}=$ standard error.

c Significantly different from the control at $P=0.01$. Calculation was done using Student's $t$ test.

${ }^{\mathrm{d}}$ The phenological stages described by Abendroth et al. (2011) are as follows: $\mathrm{VT}=$ tasseling; $\mathrm{R} 1$ = silking; and $\mathrm{R} 2$ = blister.

${ }^{\mathrm{e}} \mathrm{qPCR}=$ real-time polymerase chain reaction; and HMRT/COX ratio = H. maydis relative transcript abundance normalized to cytochrome $\mathrm{c}$ oxidase transcript. 
Statistical analyses. When assessing the $H$. maydis infection outcome on the symptoms in the in vitro seed inoculation, in the growth chamber sprout infection, in the greenhouse mature plant infection, or in diseased field plants, we used complete randomized statistical designs. Student's $t$ test (with a significance threshold of $P=0.05$ ) was used for comparisons of treatment means to the control.

\section{Results}

Our research strategy was to evaluate the efficiency of selected fungicide seed coatings in a series of four experiments that would gradually increase the investment in time and work without wasting effort if the treatment had not successfully passed the early steps. The first stage was an evaluation of the seed coating in vitro (seed inoculation in an Erlenmeyer flask). The second stage was a seedling assay (sprouts up to the age of 6 weeks) in a growth chamber. The third stage was an evaluation of the treatment in potted plants over a full growth period (from seed to seed) in a greenhouse. The fourth and last stage was a field assay. Here, we present the AS treatment that successfully passed all four stages. Other fungicides that failed in the early stages are not presented.

$H$. maydis qPCR detection method. The qPCR assay reliably detected $H$. maydis DNA from all sample types except for the negative controls: axenic maize tissue and the no-template control wells. This qPCR assay detected $H$. maydis DNA at concentrations ranging from $15 \mathrm{pg} / \mu \mathrm{l}$ down to as low as $0.3 \mathrm{pg} / \mu \mathrm{l}$ (Fig. 1A). A melting curve analysis showed a single peak corresponding to the primer amplicon (Fig. 1B). In the in vitro seed pathogenicity experiment (Fig. 2) and in the greenhouse assay (full growth period, Table 2), the qPCR identification of the incidence of infection in the inoculated or infested treatments was $100 \%$. Nevertheless, the qPCR identified only $54 \%$ of the deliberately infected plants in the sprout pathogenicity assay (in a growth chamber up to 40 DAS). In this experiment, we used a commercial soil mixture and added colony agar disks for the inoculation. This method was inconsistent and failed to cause significant symptoms in mature plants (age 70 days or more, $\mathrm{O}$. Degani et al., unpublished data). We therefore applied a different method in the greenhouse assay (full growth period) and used the
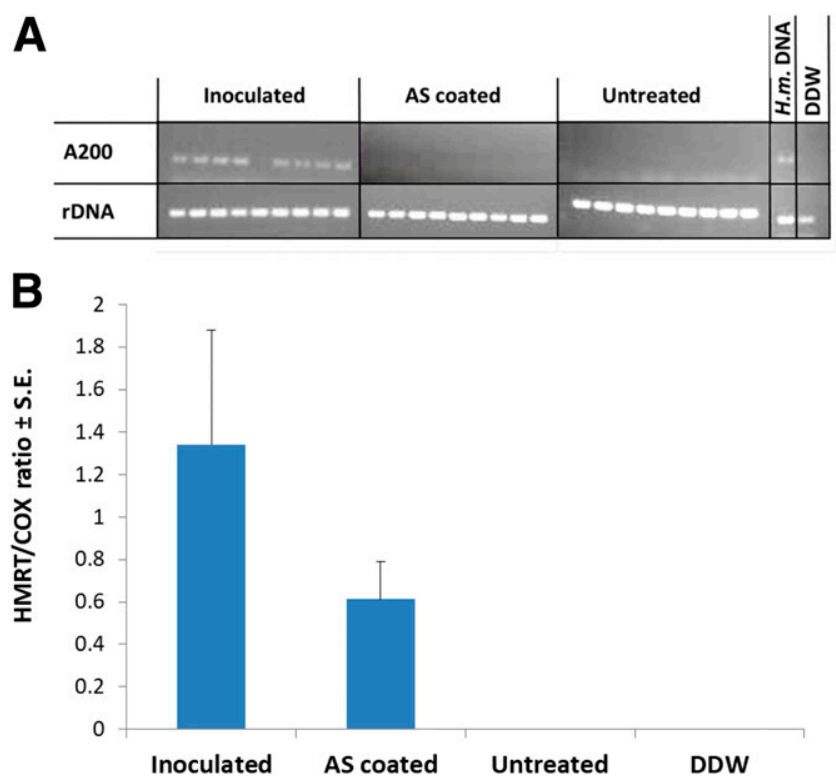

Fig. 3. Molecular diagnosis of the azoxystrobin (AS) seed coating in vitro assay (described in the caption for Figure 2). A, Electrophoresis results show polymerase chain reaction (PCR) amplification of the unique Harpophora maydis oligonucleotide (A200, upper panel) and rDNA (18S eukaryotic ribosomal DNA, lower panel). B, Real-time PCR analysis of $H$. maydis unique oligonucleotide. Values indicate an average of five replicates. Error bars indicate standard errors. H.m. DNA = isolate $\mathrm{Hm}-2$ DNA extracted from a potato dextrose agar colony used as positive control for the PCR; DDW = double-distilled water used as a template in the PCR mixture to ensure the absence of DNA contamination; and HMRT/COX $=H$. maydis relative transcript abundance normalized to the cytochrome $\mathrm{c}$ oxidase transcript. inoculum method, consisting of a naturally infested soil with a complementary inoculation, as described in the Materials and Methods section.

Effects of AS fungicide on seed infection in vitro. In this study, we tested seeds coated with AS. The fungicide was selected after its success in suppressing the pathogen's in vitro culture growth (Degani and Cernica 2014) and preventing its attack in the field (Degani et al. 2014). Coating the seeds with AS solution under control conditions in Erlenmeyer flasks minimized the $H$. maydis suppression influence on seed germination, and the difference from the control decreased from being significant, $P=0.022$, to nonsignificant, $P=0.063$. The seed dressing also had a positive promotion effect on growth, expressed as fresh biomass (from a significant difference from the control of $P=2.83 \times 10^{-4}$ to a significant difference of $P=0.043$ ). There was no phytotoxic side effect to the seed coating (Fig. 2). These treatments totally blocked the conventional PCR detection of the pathogen inside the infected seeds (Fig. 3A). However, the qPCR evaluation revealed that the seed coating managed to reduce pathogen DNA levels inside the seeds only by half (Fig. 3B).

Effect of AS seed coating on emerging seedlings. A test for pathogenesis in sprouts (up to 40 days, four to five-leaves stage) in a growth chamber was developed previously in our lab (Degani and Cernica 2014) and used here (Table 3) together with the new qPCR detection to identify a preferred infection method. Two inoculation techniques were chosen for the seedling pathogenicity experiments presented here: adding hyphal suspension to each seed with the sowing and covering the seeds with hyphae before planting (dipping the seeds overnight in hyphal suspension). In a growth chamber, and as early as 6 weeks after inoculation, $H$. maydis caused evident decreases in the emergence and weight in both roots and aboveground parts of the maize host plants (Table 3). From the two abovementioned inoculation methods, the direct application of hyphal suspension (fungal inoculation) produced more noticeable symptoms. In this treatment, the AS seed coating reduced $H$. maydis suppression

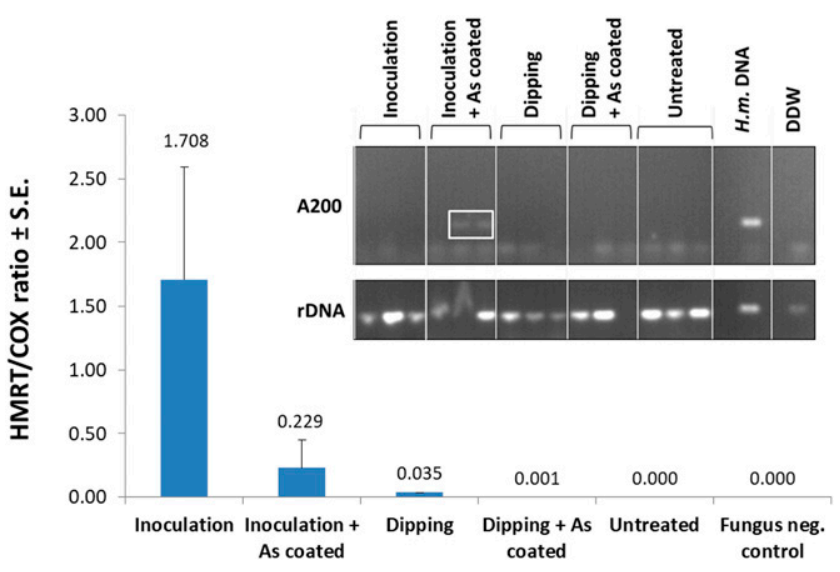

Fig. 4. Effect of azoxystrobin (As) seed coating on emerging seedlings. Molecular diagnosis of late wilt in maize plant samples of the sensitive cultivar Jubilee using polymerase chain reaction (PCR) amplification (inset photo) or real-time PCR (graph). The experimental plants' symptoms are described in Table 3. Two infection methods were used: inoculation (adding $200 \mathrm{mg}$ of mycelium suspension directly to each seed with the sowing) or dipping (covering the seeds with hyphae by dipping them overnight in hyphal suspension before seeding). Seed coating was done as described in the caption for Figure 2. Each treatment included five independent replications (pots), each containing five plants. To identify the fungus in the host plant tissues, plants (30 days old) were sampled by removing a cross-section of approximately $2 \mathrm{~cm}$ in length from each plant. Tissue samples from the five plants of each pot were combined, and the total weight was adjusted to $0.4 \mathrm{~g}$ and considered to be one repeat. The only positive identification of the fungal DNA presence in the PCR detection is marked by a white square. Error bars indicate standard errors. A200 = unique Harpophora maydis oligonucleotide; rDNA = 18S eukaryotic ribosomal DNA; H.m. DNA = isolate Hm-2 DNA extracted from a potato dextrose agar colony used as positive control for the PCR; DDW = double-distilled water used as a template in the PCR mixture to ensure the absence of DNA contamination; and HMRT/COX $=H$. maydis relative transcript abundance normalized to the cytochrome $\mathrm{c}$ oxidase transcript. 
on sprout emergence, root biomass, and aboveground parts biomass by 17,41 , and $39 \%$, respectively (compared with the infected, untreated control plants). In the fungus dipping treatment (covering of the seeds with hyphae), there was one exception when the AS seed coating caused a phytotoxic effect, decreasing the plant height significantly $(P=0.01)$. This effect was not expressed in the root or shoot wet biomass, which remained in both cases higher in the AS treatment, compared with the control. Seed coating with AS alone (with no fungal inoculation) caused a $29 \%$ decrease in sprout emergence after 7 days, but this difference from the control was not apparent in the wet weight measurements of the plants' roots and shoots on day 30 .

The conventional PCR monitoring method failed to detect changes in fungal DNA under the influence of the seed coating owing to its sensitivity limitation (Fig. 4, inset). On the other hand, the qPCR method revealed the efficiency of the AS coating in reducing $H$. maydis DNA in host plant tissues (Fig. 4). Similar to the disease symptom evaluation, in this criterion (qPCR tracking) as well, the inoculation method achieved more noticeable results (higher fungal DNA levels) compared with the dipping technique (covering the seeds with hyphae by dipping them overnight in hyphal suspension before seeding).

Effect of AS seed coating on mature plants. In a greenhouse plant over a full growth period, the coating treatment reduced wilting (32\%) and shoot wet biomass loss $(26 \%)$ and led to low $H$. maydis DNA residues (91\% fungal DNA inhibition) (Table 2). However, the seed coating negatively influenced plant development, reducing sprout emergence (32\% inhibition, $P=0.01$ ) and phenological development to the blister (stage R2, 60\% inhibition). This implies that some phytotoxicity exists in the applied AS fungicide concentration.

Effect of AS seed coating in the field. To study the disease progression from 10 DAS until maturity, we conducted a field experiment in a maize field in Kibbutz Amir in the Hula Valley (Upper Galilee, northern Israel) during the spring and summer of 2016. Plant samples were collected at 10-day intervals, and DNA was isolated from each sample for later diagnosis. Conventional PCR and qPCR were conducted collectively at the end of the growth period. Overall analysis combining the two sweet maize hybrids (cultivars Prelude and Royalty) and the two fodder maize hybrids (cultivars p32w86 and 32D99) shows that the qPCR first identifies the pathogen 20 DAS (Fig. 5), 20 to 30 days before conventional PCR detection (Drori et al. 2013) and the appearance of the disease's earliest symptoms. The unique $H$. maydis segment identification levels increased gradually from 53\% (on day 20) to 89\% (on day 30 ) and to $100 \%$ (from day 40 onward).

As mentioned in the Materials and Methods section, two representative maize hybrids were chosen for a close inspection analysis: the Prelude (late wilt sensitive) and 32D99 (late wilt resistant) cultivars. These were selected because they are extreme cultivars that differ in many aspects other than susceptibility. Although a close inspection of the pathogenesis in a sensitive maize cultivar in comparison with a resistant cultivar using PCR tracking was already demonstrated in earlier studies (Degani and Cernica 2014; Drori et al. 2013), it is interesting to examine the differences in the H. maydis pathogenesis in the two new hybrids, which to date have not been studied, using the novel qPCR detection method and to evaluate their response to the AS seed coating treatment efficiency.

In comparison with the qPCR method, the conventional PCR resultant electrophoretic gel provides similar but less accurate and less sensitive results (Fig. 6A). For example, both methods reported similar H. maydis DNA levels in the AS-treated and untreated infected cultivar Prelude but a drastic reduction in fungal DNA levels as a result of the AS seed coating in the cultivar 32D99 (Fig. 6). However, the qPCR method identified a reduction in the $H$. maydis relative gene expression in the cultivar Prelude on day 60 post-sowing in comparison with day 30, which was not evident in the PCR results.

Progression of disease symptoms in cultivar Prelude plants followed quantitative changes in fungal DNA estimated by the qPCR analysis. A peak in the fungal DNA isolated from the roots was recorded in the cultivar 32D99 30 DAS (Fig. 6B). In the cultivar Prelude, the total amount of fungal DNA increased gradually, peaking in the root and stem on 50 DAS. At approximately this time, the plants were fertilized, and early signs of the disease started to appear. Later, from day 50 onward, the fungal DNA in the stem decreased until it reached a near-zero level on day 70 post-sowing. At this age, 20 days after pollination, almost all of the cultivar Prelude plants were already

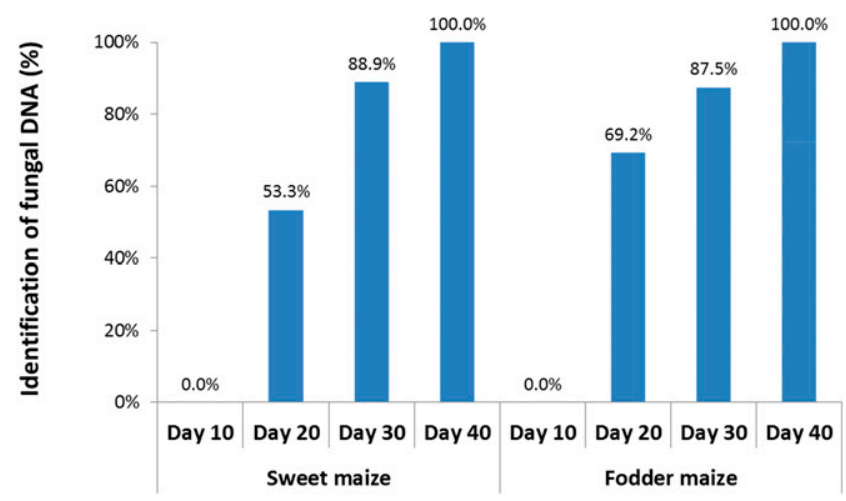

Fig. 5. Real-time polymerase chain reaction (qPCR) diagnosis of late wilt pathogenesis in the field. Assessing azoxystrobin seed coating efficiency in controlling Harpophora maydis pathogenesis was conducted during the spring and summer of 2016 in an infested field in the Hula Valley in the Upper Galilee in northern Israel. Four representative maize cultivars were evaluated in this experiment: two sweet corn cultivars (Prelude and Royalty), and two fodder cultivars (p32w86 and 32D99). Seeding was performed on 25 May 2016, and germination (with a frontal irrigation system) 1 day later. Plants emerged above the ground surface approximately 6 days after planting. Plants were first pollinated when they reached 70\% silk: sweet corn cultivars on 14 July 2016 (50 days after sowing) and fodder cultivars on 20 July 2016 (56 days after sowing). Plants were collected arbitrarily at 10-day intervals from sowing onward. DNA was extracted from the root of each plant and analyzed in three independent replications. QPCR was performed to amplify a specific $H$. maydis segment as described in Figure 1. Bars indicate mean of 13 to 24 replications of each plant group (sweet or fodder maize).

Table 3. Efficiency of the azoxystrobin (AS) seed coating on seedlings in a growth chamber ${ }^{\mathrm{a}}$

\begin{tabular}{|c|c|c|c|c|c|c|c|c|c|c|c|c|c|}
\hline \multirow[b]{3}{*}{ Assessment } & \multirow[b]{3}{*}{ Age (days after sowing) } & \multicolumn{4}{|c|}{ Fungus inoculation } & \multicolumn{4}{|c|}{ Fungus dipping } & \multicolumn{4}{|c|}{ Untreated } \\
\hline & & \multicolumn{2}{|c|}{$\mathbf{N T}^{\mathbf{b}}$} & \multicolumn{2}{|c|}{ AS } & \multicolumn{2}{|c|}{ NT } & \multicolumn{2}{|c|}{$\mathbf{A S}$} & \multicolumn{2}{|c|}{ NT } & \multicolumn{2}{|c|}{ AS } \\
\hline & & Mean & SE & Mean & SE & Mean & SE & Mean & SE & Mean & SE & Mean & SE \\
\hline Emergence $(\%)$ & 7 & 66.7 & 0.0 & 77.8 & 2.1 & 88.9 & 2.1 & 55.6 & 2.1 & 93.3 & 0.0 & 66.7 & 1.0 \\
\hline Plant height $(\mathrm{cm})^{\mathrm{c}}$ & 30 & 45.5 & 4.4 & 46.4 & 8.0 & 75.7 & 6.1 & $49.8^{\mathrm{d}}$ & 3.3 & 63.9 & 5.5 & 65.2 & 4.0 \\
\hline Root wet weight (g) & 30 & 0.39 & 0.14 & 0.55 & 0.12 & 0.38 & 0.05 & 0.42 & 0.10 & 0.41 & 0.12 & 0.42 & 0.06 \\
\hline Shoot wet weight (g) & 30 & 2.44 & 0.67 & 3.40 & 0.61 & 2.36 & 0.35 & 2.84 & 0.57 & 2.25 & 0.38 & 2.16 & 0.32 \\
\hline
\end{tabular}

a The susceptible maize genotype Jubilee was chosen for this experiment. Seed coating with AS fungicide was done by dipping the seeds in $10 \mathrm{mg} /$ liter of active ingredient for $10 \mathrm{~min}$ (final concentration of approximately $0.02 \mathrm{mg} / \mathrm{seed}$ ) and then drying them. The experiment included two inoculation methods with isolate of Harpophora maydis: fungus inoculation (direct application of hyphal suspension; $200 \mathrm{mg}$ of mycelium suspension was added to each seed with the sowing) and fungus dipping (covering of the seeds with hyphae by dipping them overnight in hyphal suspension; 10 seeds in $200 \mathrm{mg}$ of mycelium suspension). Each treatment included at least five independent replications (plants).

${ }^{\mathrm{b}} \mathrm{NT}=$ control, untreated plots; and $\mathrm{SE}=$ standard error.

${ }^{\mathrm{c}}$ The phenological stage of the plants at the age of 30 days from sowing was V5 (four to five leaves).

${ }^{\mathrm{d}}$ Significantly different from the control at $P=0.01$. Calculation was done using Student's $t$ test. 
diseased and dried out (Fig. 7, Table 4). Interestingly, in the resistant maize cultivar 32D99, the fungus DNA was clearly identified in the roots of the plant from day 20 onward but was near the discovery threshold in the stem for all measurements (Fig. 6). This cultivar showed minor signs of disease (Fig. 7, Table 4).

As previously reported (Drori et al. 2013), H. maydis slowly spreads during the first 5 weeks after maize germination. When growing susceptible maize cultivars such as Jubilee in infested commercial fields, the first symptoms of dehydration usually appeared 50 to 60 DAS, just before the tasseling stage. The disease symptoms recorded by us were similar to the data in the literature. By anthesis (flowering at 9 to 10 weeks), the lower leaves turned a muted green and then lost their color and became dehydrated (Fig. 7A). At this stage, we observed many blocked vessels. This plugging was apparently a result of hyphae and the accumulation of a dark gum-like substance (Sabet et al. 1970b). Supporting this, a longitudinal section of diseased maize plants (Fig. 7B) revealed a yellow-brown concentration near the internodes (especially in the cultivar Prelude untreated plants). The dehydration symptoms increased upward and included color alteration of the vascular bundles to a yellow-brown hue (Fig. 7C, bold with arrows) and then the appearance of red-brown stripes on the exterior surface of the lower internodes. This symptom did not always appear but was clearly visible in the untreated sample of the cultivar 32D99 (Fig. 7B). Later, stem symptoms included parenchyma tissue wet rot (softening and the appearance of brown patches in the tissue), as seen in the untreated cultivar Prelude sample cross-section (Fig. 7C). These symptoms may become more severe owing to the invasion of saprobic organisms, including $F$. verticillioides (the cause of Fusarium stalk rot) and M. phaseolina (the cause of charcoal rot), together, called the postflowering stalk rot complex (Khokhar et al. 2014). This systemic infection rot is also apparent in infested cobs (Shehata 1976), as exemplified here in the untreated cultivar Prelude sample (Fig. 7D). In severe cases of the disease, no cobs are formed. If seeds appear, they are often shrunken and undeveloped (Drori et al. 2013). Indeed, in this field experiment, the cultivar Prelude cobs were poorly developed, and a nearly total crop yield loss was recorded (Table 4).

The AS seed coating managed to rescue some of these symptoms in the sensitive cultivar Prelude. In sprouts (age 10 DAS), the AStreated plant root and shoot biomass were higher (17 and 38\%, respectively, Table 4). At 60 DAS, the chemical coating reduced stem rot and vascular occlusion symptoms (Fig. 7B and C), and at approximately 70 DAS, this treatment reduced wilting percentage by $19 \%$ (Table 4, Fig. 7A). However, at the end of the growth session at 75 DAS, the AS coating failed to protect the sensitive cultivar Prelude plants, and only a minor decrease $(4 \%)$ in dehydration in comparison with the untreated control plants was recorded (Table 4, Fig. 8). Total crop yield loss was recorded in the AS-treated cultivar Prelude plots. In comparison, in the resistant untreated cultivar 32D99 plots, fewer symptoms of late wilt appeared (Figs. 7 and 8). The H. maydis pathogen had no apparent influence on sprout development. Wilting percentage first appeared at the age of 60 DAS (10 days after fertilization). The dehydration symptoms increased to $31 \%$ on 75 DAS (Table 4). However, in the cultivar 32D99 plots, the AS coating was successful in blocking the wilting (92\% reduction, $P \leq 0.0001)$ and in recovering crop yield and plant biomass by 39 and $60 \%$, respectively (Table 4).

\section{Discussion}

In Mediterranean countries such as Egypt, Israel, India, and Spain, H. maydis causes severe economic losses in maize growth (Drori et al. 2013; Ortiz-Bustos et al. 2016; Payak et al. 1970; Sabet et al. 1970b). Because fungicide treatment limitation exerts increasing pressure in many countries, the current control of phytopathogenic fungi tends to rely on host resistance and agromechanics procedures. These methods are currently being used for late wilt restriction in Israel. However, H. maydis isolates are known to have variation in aggressiveness and pathogenicity (El-Assiuty et al. 1988; Zeller et al. 2002), and new virulent fungal strains could arise; therefore, seeking new alternative ways to control the disease is an ongoing mission.
Seed treatments are commonly applied for management purposes, but traditional methods for evaluating seed coating efficiency are time-consuming and not productive (Anderson et al. 2015). Hence, to achieve an improved evaluation of seed-treatment fungicides, we developed a sensitive and accurate qPCR-based seedling assay for $H$. maydis infection. We had already used established infection and inoculation conditions (Degani and Cernica 2014) to achieve high infection incidence in comparison with the untreated controls, but some additional improvements to these methods were developed

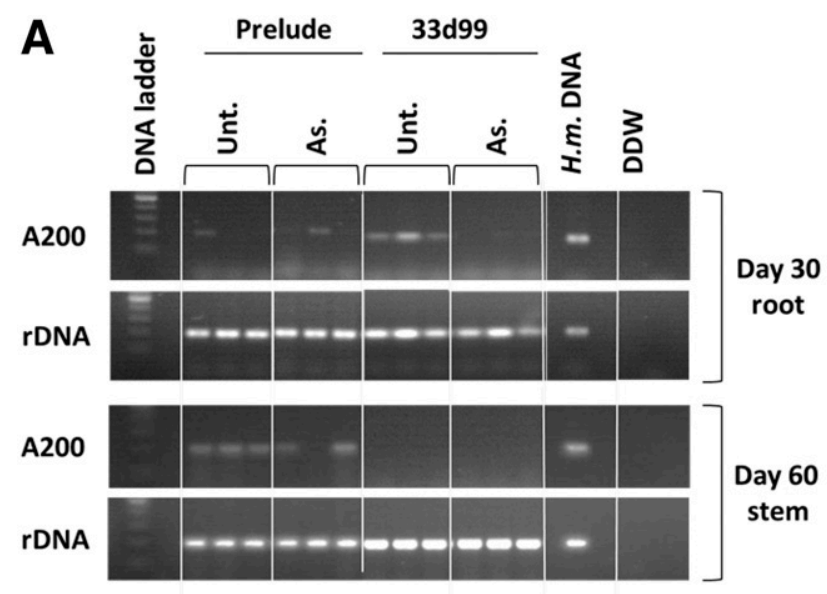

B

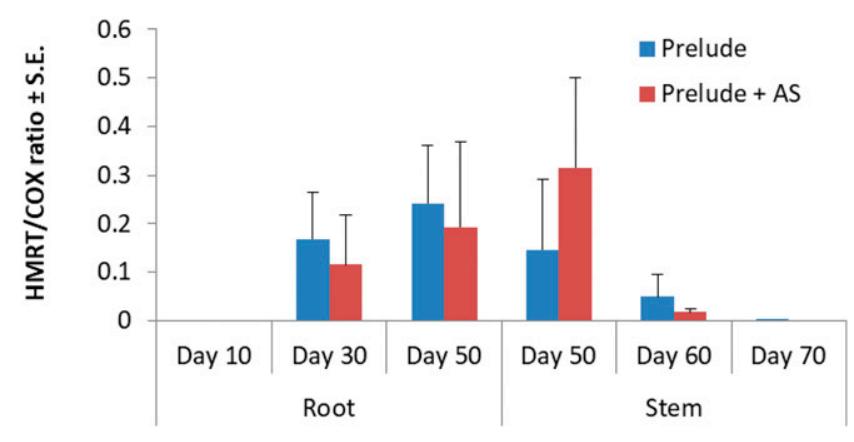

C $32 d 99$

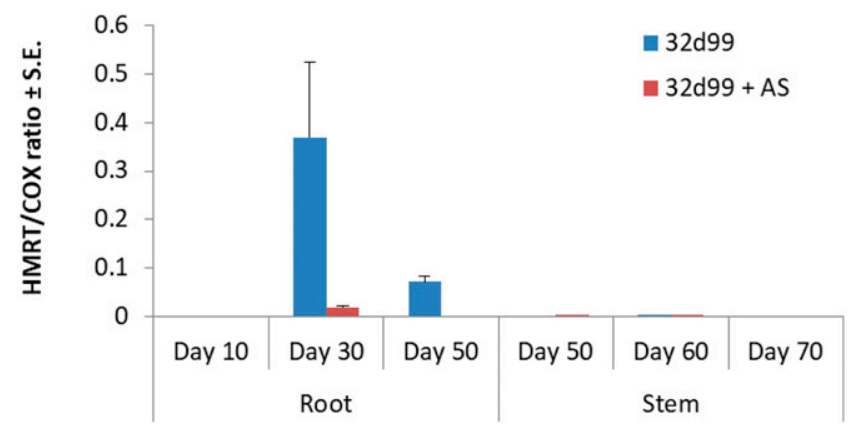

Fig. 6. Effect of azoxystrobin (As., AS) seed coating in the field. Molecular diagnosis of late wilt in maize plant samples in the field experiments described in the caption to Figure 5. Two of the maize cultivars were selected for in-depth molecular evaluation: the susceptible cultivar of sweet corn Prelude and the resistant fodder cultivar 32D99. Root samples (taken 10, 30, and 50 days after sowing) and stem samples (taken 50, 60 , and 70 days after sowing) were inspected for the presence of the pathogen using polymerase chain reaction (PCR) $(A)$ or real-time PCR (B and $C$ ) amplification of the unique Harpophora maydis oligonucleotide (marked as A200 in the PCR, gel electrophoresis results). Vertical upper bars represent the standard error of the mean of three representative plants sampled arbitrarily from each cultivar. Unt. = untreated; H.m. DNA = isolate Hm-2 DNA extracted from a potato dextrose agar colony used as positive control for the PCR; DDW = double-distilled water used as a template in the PCR mixture to ensure the absence of DNA contamination; and $\mathrm{HMRT} / \mathrm{COX}=H$. maydis relative transcript abundance normalized to the cytochrome c oxidase transcript. 
in this study (for example, the greenhouse pathogenicity assay, Table 2).

Our research design aimed at progressing from in-lab seed coating evaluation to greenhouse experiments (while eliminating inefficient compounds or application techniques) and eventually testing the most promising treatment in infested fields. Testing the efficacy of seed treatments cannot be accomplished without field experiments and observations of disease symptoms. However, not only are field experiments costly and time-consuming, they usually rely on natural soil infestation, which can lead to highly variable results. Differences in weather can also contribute to variable experimental results, particularly if the infection is reduced under conditions of extremely wet soils or extreme temperatures. Indeed, our experience (Degani and Goldblat 2014; Degani et al. 2014) and a review of the literature support the conclusion that high water potential is one of the most important factors restricting late wilt disease progression (Abd ElRahim et al. 1998; El-Shafey et al. 1988; Samra et al. 1966; Singh and Siradhana 1988).

Although an in vitro effect of fungicides does not always provide a good criterion for in vivo performance (Demirci et al. 2003), rapid screening of a synthetic pesticide is mostly achieved under controlled conditions and is an important opening stage before the field experiments. Seedling pathogenicity inspection could greatly facilitate seed treatment testing by providing more consistent and rapid results, without the risk of unintentionally spreading the pathogen. To this end, we developed and validated a qPCR assay that enables detecting and tracking $H$. maydis and its interactions with the maize host plant under control conditions in the early growth stages, in which the
A

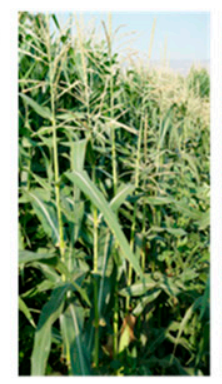

Prelude

B
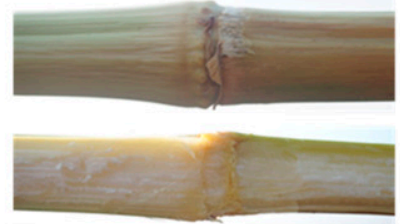

Prelude
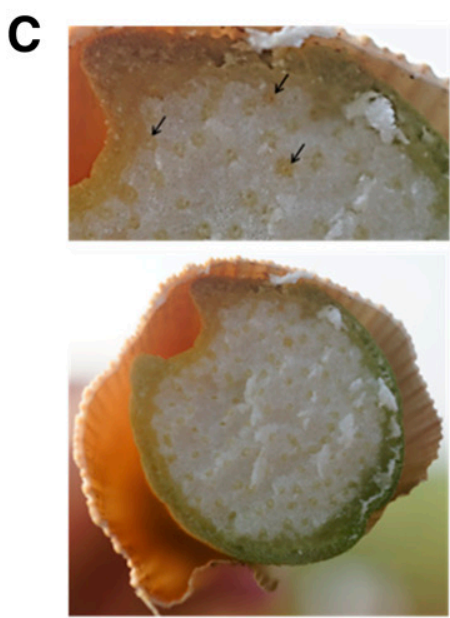

Prelude

D

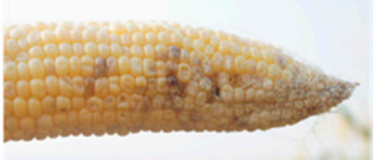

Prelude

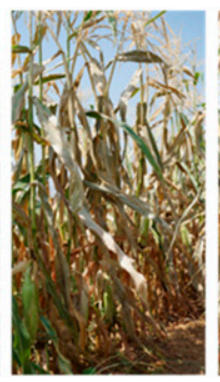

Prelude

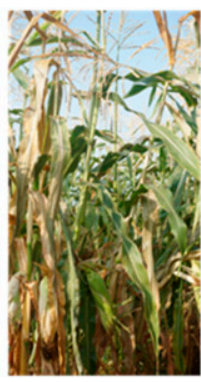

Prelude + AS
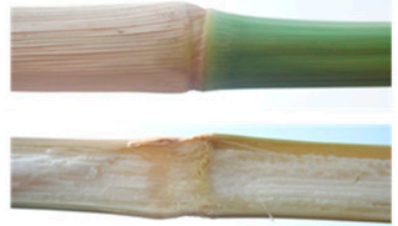

Prelude + AS
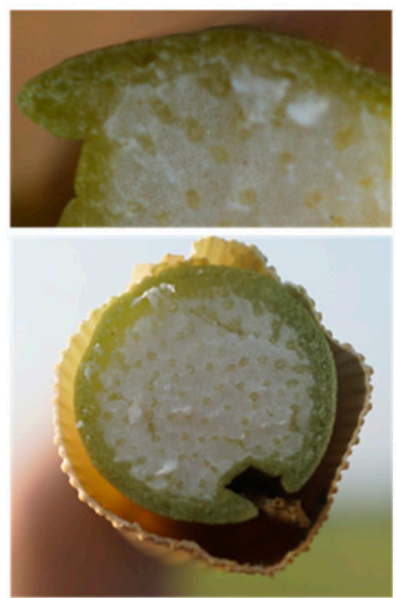

Prelude + AS

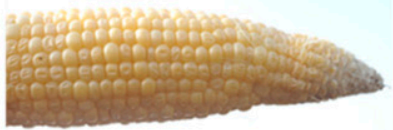

Prelude + AS

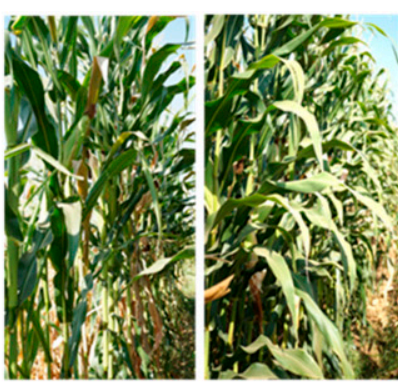

$32 D 99+A S$

32D99
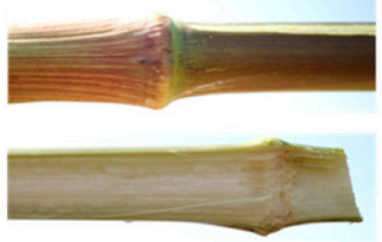

32D99
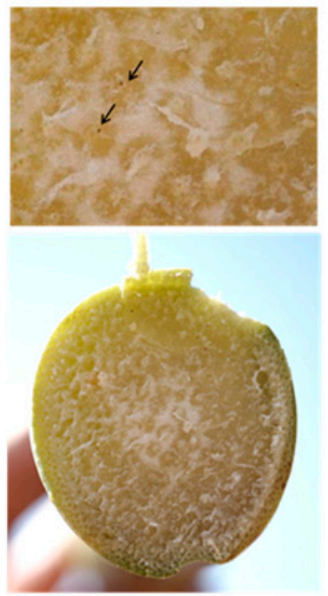

32D99

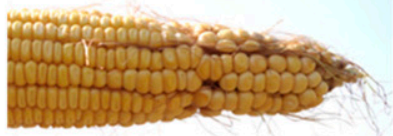

32D99
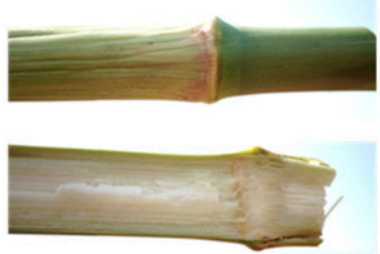

32D99 + AS
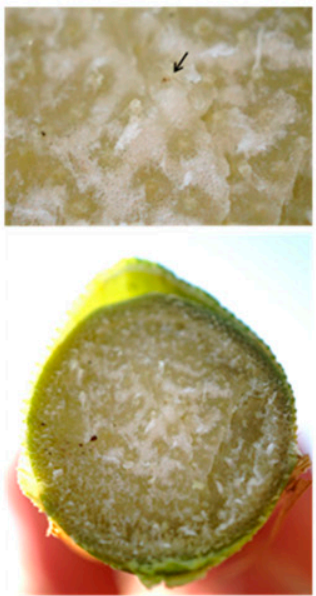

$32 D 99+A S$

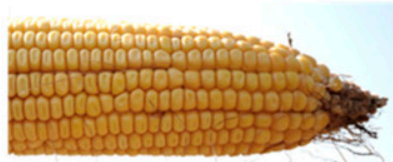

32D99 + AS

Fig. 7. Late wilt disease symptoms in the field experiment for assessing azoxystrobin (AS) seed coating (described in the caption to Figure 5). A, Wilt symptoms: drying out ascends upward in the plant, including stem and leaf yellowing and dehydration. Wilted cultivar Prelude plants photographed 62 (left) and 71 (middle) days after sowing (12 and 21 days after fertilization). The AS seed coating managed to reduce the wilting symptoms in some of the plots, but the difference was less noticeable in other plots (see also Table 4). Cultivar 32D99 plants photographed 88 days after sowing (right, 38 days after fertilization) show only minor symptoms. B, Color alteration of the two cultivars' lower stems (including the first internode above the ground) and the vascular bundles to a yellow-brown hue seen in the longitudinal section of a stem from both untreated and AS seed coating treated plants. In the untreated cultivar 32D99, the appearance of red-brown stripes on the lower internode is noticeable. C, Cross-sections of the same plants. Arrows point to blocked vascular bundles with a brown substance. D, Late wilt-infected and poorly developed maize cobs from the same plants. Notice the appearance of rot patches in the untreated cultivar Prelude. These symptoms may be caused by secondary invaders: saprobic phytopathogenic fungus, involving a postflowering stalk rot complex. 
disease symptoms are usually minor and barely detected. In particular, we used this method for assessing chemical seed dressing with AS against the maize late wilt causal agent.

The AS seed coating tested here is effective in reducing $H$. maydis infection. Although this treatment cannot be used alone to protect sensitive maize hybrids in heavily infested fields, it provides an additional layer of protection. Thus, the seed coating has positive implications for late wilt management both in terms of cost efficiency and avoidance of potential phytotoxic effects on the crops, especially in semisensitive maize hybrids (demonstrated in Table 4, cultivar 32D99 plots) or when an infestation of the field is not severe.

It is feasible to determine the quantity of $H$. maydis DNA using the qPCR assay developed in this study. However, the relationship between symptom development and DNA quantity is unknown, and we limited our interpretation of the qPCR results to the reduction of late wilt infection incidence with fungicide seed treatments. Plants are known to be susceptible to late wilt only for a short period during the seedling stage (Sabet et al. 1970b). Therefore, prevention of seedling infection can be assumed to be an effective disease management tactic. Apparently, the prevention of seedling infection correlated to a reduced risk of disease and, thus, can be used to evaluate the efficacy of seed treatment. The assay developed here can be used to perform DNA quantification, but the relationship between the observed levels of pathogen DNA in different plant tissues and plant developmental stages to ultimate disease burst (Figs. 5, 6, and 7) must be supported in future studies. These results could be used to explain disease development and host resistance mechanisms, as demonstrated here (Fig. 6). With the sprout pathogenicity assay, environmental conditions can be controlled to imitate requirements that result in high infection occurrence of $H$. maydis. It is under these conditions that the true potential of a seed treatment to combat late wilt can be demonstrated.

It was shown earlier that the pathogen is present in the host tissues of successfully treated plants (Degani et al. 2014). This hints at the potential risk that the pathogen will develop immunity to fungicides. Therefore, combining two or more active ingredients with a different mode of action may be crucial for preventing the development of fungal resistance. AS is a member of the quinone outside inhibitor (QoI) fungicide class, which is considered one of the most important classes of agricultural fungicides (Fernández-Ortuño et al. 2010). Unfortunately, the rapid development of resistance to these fungicides and the consequent control failure have become increasingly problematic (see, for example, in Magnaporthe grisea [Avila-Adame and Koller 2003]). Resistance to AS has been known to occur in various fungal species and target site mutations in the cyt $b$ gene (G143A and F129L) and additional mechanisms. Cross-resistance has also been shown to occur among all members of the QoI group (Fungicide Resistance Action Committee Code List 2018). Thus, further research with AS and other fungicides is crucial for late wilt control.
In a field experiment, the gradual reduction in detectable $H$. maydis DNA inside the host stem toward 70 DAS implies a decrease in fungal cell biomass that may result in degradation of the fungal DNA. We measured this reduction in DNA levels from previous field assays at the stage when the plants show severe dehydration (O. Degani et al., unpublished data). We hypothesized that when approaching the end of the growth session when the host tissues dry out, the fungus enters the asexual reproduction stage and develops spores and sclerotial bodies (Johal et al. 2004), and the main hyphae biomass gradually comes apart. This assumption should be examined in future studies.

\section{Conclusions}

In this work, In vitro and in vivo evaluations proved the effect of AS seed coating on the $H$. maydis pathosystem in maize. It was also demonstrated that seed coating efficacy could be assessed accurately and efficiently under various growth conditions using a specific qPCR-based assay. The methodology demonstrated in this work could have applications such as in vivo inspection, not only of fungicides but also of other types of novel treatments to control

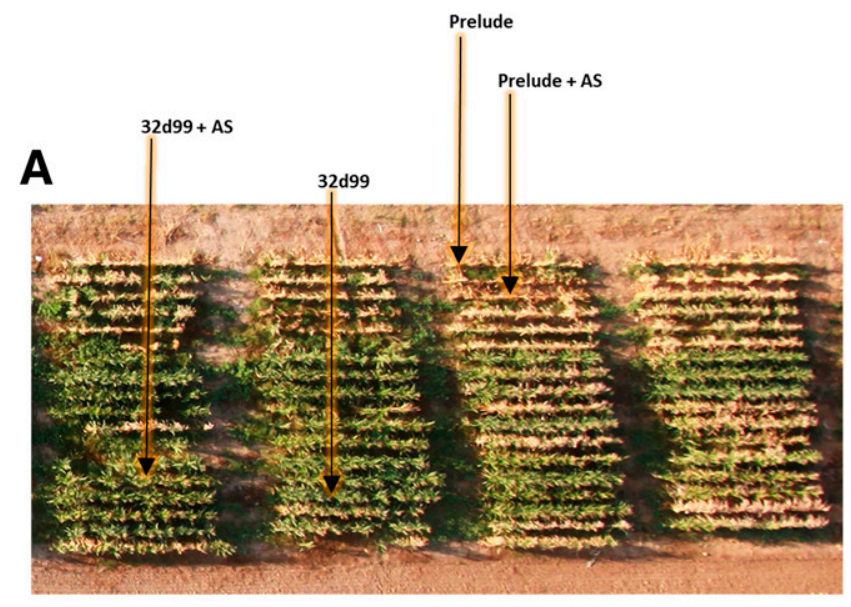

B

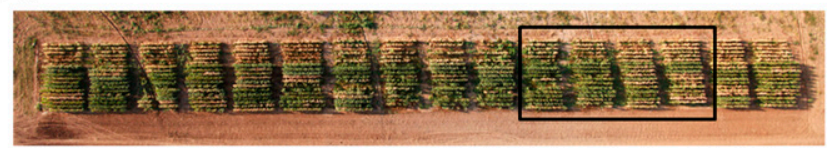

Fig. 8. Aerial photograph of the field experiments for assessing azoxystrobin (AS) seed coating (described in the caption to Figure 5). A, Close-up of a portion of the experimental field. $\mathbf{B}$, The whole field in which the portion shown in A is marked by a black box. The control (untreated) and fungicide (AS) treated groups of cultivars Prelude and 32D99 maize plants in the field were photographed by Asaf Solomon 87 days after sowing ( 37 days after fertilization).

Table 4. Efficiency of the azoxystrobin (AS) seed coating in the field

\begin{tabular}{|c|c|c|c|c|c|c|}
\hline \multirow[b]{2}{*}{ Assessment } & \multicolumn{3}{|c|}{ Prelude $^{\mathbf{a}}$} & \multicolumn{3}{|c|}{ 32D99 } \\
\hline & DAS & NT & AS & DAS & NT & AS \\
\hline Root wet weight $(\mathrm{g} \pm \mathrm{SE})$ & 10 & $0.53 \pm 0.06$ & $0.62 \pm 0.12$ & 10 & $0.57 \pm 0.07$ & $0.67 \pm 0.04$ \\
\hline Shoot wet weight $(\mathrm{g} \pm \mathrm{SE})$ & 10 & $1.77 \pm 0.10$ & $2.44 \pm 0.28$ & 10 & $3.13 \pm 0.22$ & $2.60 \pm 0.34$ \\
\hline Wilting $^{\mathrm{b}}(\%)$ & 69 & 60.0 & 48.6 & 84 & 2.5 & $0.0^{\mathrm{c}}$ \\
\hline & 75 & 100 & 96.3 & 99 & 31.3 & $2.5^{\mathrm{c}}$ \\
\hline Yield $(\mathrm{kg})^{\mathrm{d}}$ & 77 & 0.0 & 0.0 & 102 & $7.47 \pm 1.39 \mathrm{cob}, 10.23 \pm 1.60$ plant & $10.39 \pm 2.34 \mathrm{cob}, 16.37 \pm 3.64$ plant \\
\hline
\end{tabular}

${ }^{\text {a }} \mathrm{NT}=$ control, untreated plots; and DAS = days after sowing.

${ }^{\mathrm{b}}$ Dehydration assessment was done 19 and 25 days after fertilization in sensitive sweet maize cultivar Prelude and 34 and 49 days after fertilization in the resistant fodder maize cultivar 32D99. Wilt determination was done by calculating the percentage of plants showing typical late wilt dehydration symptoms: color alteration of the upper leaves to light silver and then to light brown, and rolling inward from the edges of the entire leaf. Results represent the average of six replications.

c Significance from the control at $P \leq 0.0001$. Calculation was done using Student's $t$ test.

d Yield assessment was done 27 days after fertilization in the cultivar Prelude and 52 days after fertilization in the cultivar 32D99. Yield determination included all the upper part plant cobs in a 5-m-long section of each of the experimental rows. The sensitive cultivar Prelude plots were collapsed, and on harvest day, total yield loss was recorded. To evaluate the plant and cob weight in the fodder cultivar 32D99, two to four representative plants from each plot were selected arbitrarily (25 to 30 cobs or plants per treatment in total). 
maize late wilt. Moreover, rapid, accurate, and sensitive diagnostic tests such as these may be of powerful assistance in the effort to characterize the distribution of $H$. maydis and prevent its spread into pathogen-free areas.

\section{Acknowledgments}

We thank Shaul Graph (Migal - Galilee Research Institute, Israel) for his support and helpful advice, and Roan Halabi, Uri Bar, and Heba Riad Shawahni (TelHai College, Israel) for their technical assistance. The experiments comply with the current laws of Israel.

\section{Literature Cited}

Abd El-Rahim, M. F., Fahmy, G. M., and Fahmy, Z. M. 1998. Alterations in transpiration and stem vascular tissues of two maize cultivars under conditions of water stress and late wilt disease. Plant Pathol. 47:216-223.

Abd-el-Rahim, M. F., Sabet, K. A., El-Shafey, H. A., and El-Assiuty, E. M. 1982. Chemical control of the late wilt disease of maize caused by Cephalosporium maydis. Agric. Res. Rev. 60:31-49.

Abendroth, L. J., Elmore, R. W., Boyer, M. J., and Marlay, S. K. 2011. Corn growth and development. PMR 1009. Iowa State University Extension, Ames, IA.

Anderson, S., Simmons, H., and Munkvold, G. 2015. Real-time PCR assay for detection of Sphacelotheca reiliana infection in maize (Zea mays) seedlings and evaluation of seed treatment efficacy. Plant Dis. 99:1847-1852.

Avila-Adame, C., and Koller, W. 2003. Characterization of spontaneous mutants of Magnaporthe grisea expressing stable resistance to the Qo-inhibiting fungicide azoxystrobin. Curr. Genet. 42:332-338.

Begum, H., Mohammad, S., Rao, G. K., and Raj, R. B. 1989. Influence of seed dressing fungicides on the incidence of post flowering stalk rot (late wilt and charcoal rot), yield and profitability of maize. Crop Res. Hisar 2:142-146.

Bergstrom, G., Leslie, F. J., Huber, D., Lipps, P., Warren, H., Esker, P., Grau, C., Botratynski, T., Bulluck, R., Floyd, J., Bennett, R., Bonde, M., Dunkle, L., Smith, K., Zeller, K., Cardwell, K., Daberkow, S., Bell, D., and Chandgoyal, T. 2008. Recovery plan for late wilt of corn caused by Harpophora maydis syn. Cephalosporium maydis. Page 24. National Plant Disease Recovery System (NPDRS), U.S.A.

Costanzo, S., Zeller, K., and Nakhla, M. 2013. A conventional PCR and qPCR assays to detect Harpophora maydis - The causal agent of late wilt of corn. Phytopathology 103:S2.30.

Degani, O., and Cernica, G. 2014. Diagnosis and control of Harpophora maydis, the cause of late wilt in maize. Adv. Microbiol. 4:94-105.

Degani, O., and Goldblat, Y. 2014. Ambient stresses regulate the development of the maize late wilt causing agent, Harpophora maydis. Agric. Sci. 5:571-582.

Degani, O., Weinberg, T., and Graph, S. 2014. Chemical control of maize late wilt in the field. Phytoparasitica 42:559-570.

Demirci, F., Bayraktar, H., Babalioğullu, I., Dolar, F. S., and Maden, S. 2003. In vitro and in vivo effects of some fungicides against the chickpea blight pathogen, Ascochyta rabiei. J. Phytopathol. 151:519-524.

Drori, R., Sharon, A., Goldberg, D., Rabinovitz, O., Levy, M., and Degani, O. 2013. Molecular diagnosis for Harpophora maydis, the cause of maize late wilt in Israel. Phytopathol. Mediterr. 52:16-29.

El-Assiuty, E. M., El-Hamahmy, A. A., and El-Sharkawy, A. Y. 1991. Bacillus subtilis, Pseudomonas fluorescens and Verticillium tricorpus as biological agents against late-wilt of maize. Egypt. J. Appl. Sci. 6:824-829.

El-Assiuty, E. M., El-Shafey, H. A., Ismael, A.-S., and Fahmy, Z. M. 1988. Pathogenic variation in Cephalosporium maydis. Phytopathology 88:S25.

El-Gremi, S. M. A., Belal, E. B. A., and Ghazy, N. A. 2007. Cephalosporium maydis as affected by maize root exudates and role of the fungal metabolites in pathogenesis. J. Agric. Sci. Mansoura Univ. 32:7605-7615.

El-Hosary, A. A. A., and El-Fiki, I. A. I. 2015. Diallel cross analysis for earliness, yield, its components and resistance to late wilt in maize. Int. J. Agric. Sci. Res. 5:199-210.

El-Mehalowy, A. A., Hassanein, N. M., Khater, H. M., Daram El-Din, E. A., and Youssef, Y. A. 2004. Influence of maize root colonization by rhizosphere actinomycetes and yeast fungi on plant growth and on the biological control of late wilt disease. Int. J. Agric. Biol. 6:599-605.

El-Shafey, H. A., and Claflin, L. E., eds. 1999. Late Wilt. APS Press, St. Paul, MN.

El-Shafey, H. A., El-Shorbagy, F. A., Khalil, I. I., and El-Assiuty, E. M. 1988. Additional sources of resistance to the late-wilt disease of maize caused by Cephalosporium maydis. Agric. Res. Rev., Egypt 66:221-230.

Fayzalla, E., Sadik, E., Elwakil, M., and Gomah, A. 1994. Soil solarization for controlling Cephalosporium maydis, the cause of late wilt disease of maize in Egypt. Egypt J. Phytopathol. 22:171-178.

Fernández-Ortuño, D., Torés, J. A., De Vicente, A., and Pérez-García, A. 2010. Mechanisms of resistance to QoI fungicides in phytopathogenic fungi. Int. Microbiol. 11:1-9.

Freeman, J., and Ward, E. 2004. Gaeumannomyces graminis, the take-all fungus and its relatives. Mol. Plant Pathol. 5:235-252.

Fromont-Racine, M., Senger, B., Saveanu, C., and Fasiolo, F. 2003. Ribosome assembly in eukaryotes. Gene 313:17-42.
Gams, W. 1971. Cephalosporium-artige Schimmelpilze (Hyphomycetes). G. Fischer, Stuttgart, Germany.

Johal, L., Huber, D. M., and Martyn, R. 2004. Late wilt of corn (maize) pathway analysis: Intentional introduction of Cephalosporium maydis. Pathways Analysis for the Introduction to the U.S. of Plant Pathogens of Economic Importance. Technical Report No. 503025. U.S. Department of Agriculture, Animal and Plant Health Inspection Service, Riverdale, MD

Khokhar, M. K., Hooda, K. S., Sharma, S. S., and Singh, V. 2014. Post flowering stalk rot complex of maize-Present status and future prospects. Maydica 59: 226-242.

Michail, S. H., Abou-Elseoud, M. S., and Nour Eldin, M. S. 1999. Seed health testing of corn for Cephalosporium maydis. Acta Phytopathol. Entomol. Hung. 34:35-42.

Molinero-Ruiz, M. L., Melero-Vara, J. M., and Mateos, A. 2010. Cephalosporium maydis, the cause of late wilt in maize, a pathogen new to Portugal and Spain. Plant Dis. 94:379.

Muhammad, S., and Amusa, N. A. 2003. In vitro inhibition of growth of some seedling blight inducing pathogens by compost-inhabiting microbes. Afr. J. Biotechnol. 2:161-164.

Murray, M., and Thompson, W. F. 1980. Rapid isolation of high molecular weight plant DNA. Nucleic Acids Res. 8:4321-4326.

Ortiz-Bustos, C. M., Testi, L., García-Carneros, A. B., and Molinero-Ruiz, L. 2016. Geographic distribution and aggressiveness of Harpophora maydis in the Iberian peninsula, and thermal detection of maize late wilt. Eur. J. Plant Pathol. 144:383-397.

Payak, M. M., Lal, S., Lilaramani, J., and Renfro, B. L. 1970. Cephalosporium maydis-A new threat to maize in India. Indian Phytopathol. 23:562-569.

Pecsi, S., and Nemeth, L. 1998. Appearance of Cephalosporium maydis Samra Sabet and Hingorani in Hungary. Meded. - Fac. Landbouwkd. Toegepaste Biol. Wet. (Univ. Gent) 63:873-877.

Sabet, K. A., Samra, A. S., and Abdel-Rahim, M. F. 1972. Systemic action of benomyl against late-wilt disease of maize. Ann. Appl. Biol. 71:211-218.

Sabet, K. A., Samra, A. S., Hingorani, M. K., and Mansour, I. M. 1961. Stalk and root rots of maize in the United Arab Republic. FAO Plant Prot. Bull. 9: 121-125.

Sabet, K. A., Samra, A. S., and Mansour, I. M. 1970a. Saprophytic behaviour of Cephalosporium maydis and C. acremonium. Ann. Appl. Biol. 66: 265-271.

Sabet, K. A., Samra, A. S., and Mansour, I. S. 1966. Interaction between Fusarium oxysporum f. vasinfectum and Cephalosporium maydis on cotton and maize. Ann. Appl. Biol. 58:93-101.

Sabet, K. A., Zaher, A. M., Samra, A. S., and Mansour, I. M. 1970b. Pathogenic behaviour of Cephalosporium maydis and C. acremonium. Ann. Appl. Biol. 66:257-263.

Sahab, A. F., Osman, A. R., Soleman, N. K., and Mikhail, M. S. 1985. Studies on root-rot of lupin in Egypt and its control. Egypt. J. Phytopathol. 17:23-35.

Saleh, A. A., and Leslie, J. F. 2004. Cephalosporium maydis is a distinct species in the Gaeumannomyces-Harpophora species complex. Mycologia 96:1294-1305.

Saleh, A. A., Zeller, K. A., Ismael, A. S., Fahmy, Z. M., El-Assiuty, E. M., and Leslie, J. F. 2003. Amplified fragment length polymorphism diversity in Cephalosporium maydis from Egypt. Phytopathology 93:853-859.

Samra, A. S., Sabet, K. A., and Abdel-Rahim, M. F. 1966. Effect of Soil Conditions and Cultural Practices on Infection with Stalk Rots. U.A.R Ministry of Agriculture, Government Printing Offices, Cairo, Egypt.

Samra, A. S., Sabet, K. A., and Hingorani, M. K. 1962. A new wilt disease of maize in Egypt. Plant Dis. Rep. 46:481-483.

Samra, A. S., Sabet, K. A., and Hingorani, M. K. 1963. Late wilt disease of maize caused by Cephalosporium maydis. Phytopathology 53:402-406.

Shehata, F. A. 1976. The inheritance of resistance to late wilt caused by Cephalosporium maydis in some corn lines M.Sc. thesis. Al-Azhar, Cairo.

Singh, S. D., and Siradhana, B. S. 1987. Survival of Cephalosporium maydis, incitant of late wilt of maize. Indian J. Mycol. Plant Pathol. 17:83-85.

Singh, S. D., and Siradhana, B. S. 1988. Date of sowing in relation to late wilt disease of maize. Indian Phytopathol. 41:489-491.

Singh, S. D., and Siradhana, B. S. 1990. Effect of macro and micronutrients on the development of late wilt of maize induced by Cephalosporium maydis. Summa Phytopathol. 16:140-145.

Subedi, S. 2015. A review on important maize diseases and their management in Nepal. J. Maize Res. Dev. 1:28-52.

Warren, H. L. 1983. Potential disease problems: Late wilt of maize. Phytopathology 73:782.

Weller, S., Elphinstone, J., Smith, N., Boonham, N., and Stead, D. 2000. Detection of Ralstonia solanacearum strains with a quantitative, multiplex, real-time, fluorogenic PCR (TaqMan) assay. Appl. Environ. Microbiol. 66:2853-2858.

Yuan, J. S., Reed, A., Chen, F., and Stewart, N. C. 2006. Statistical analysis of realtime PCR data. BMC Bioinformat. 7:85.

Zeller, K. A., Abou-Serie, M. I., El-Assuity, E. M., Fahmy, Z. M., Bekheet, F. M., and Leslie, J. F. 2002. Relative competitiveness and virulence of four clonal lineages of Cephalosporium maydis from Egypt toward greenhouse-grown maize. Plant Dis. 86:373-378. 